\title{
Diversity and effectiveness of tropical mangrove soil microflora on the degradation of polythene carry bags
}

\author{
Shristi Kumar ${ }^{1}$, A.A.M. Hatha ${ }^{1,2}$ \& K.S. Christi ${ }^{1}$ \\ 1 Department of Biology, School of Pure and Applied Sciences, The University of the South Pacific, P.O. Box, 1168, \\ Suva,Fiji Islands; shristikumar@yahoo.com; christi_k@usp.ac.fj \\ 2 Department of Marine Biology, Microbiology and Biochemistry, School of Marine Sciences, Cochin University of \\ Science and Technology, Cochin - 682 016, Kerala, India; mohamedhatha@hotmail.com; \\ mohamedhatha@cusat.ac.in
}

Received 27-IV-2006. Corrected 30-XI-2006. Accepted 07-V-2007.

\begin{abstract}
The diversity and load of heterotrophic bacteria and fungi associated with the mangrove soil from Suva, Fiji Islands, was determined by using the plate count method. The ability of the bacterial isolates to produce various hydrolytic enzymes such as amylase, gelatinase and lipase were determined using the plate assay. The heterotrophic bacterial load was considerably higher than the fungal load. There was a predominance of the gram positive genus, Bacillus. Other genera encountered included Staphylococcus, Micrococcus, Listeria and Vibrio. Their effectiveness on the degradation of commercial polythene carry bags made of high density polyethylene (HDPE) and low density polyethylene (LDPE) was studied over a period of eight weeks in the laboratory. Biodegradation was measured in terms of mean weight loss, which was nearly $5 \%$ after a period of eight weeks. There was a significant increase in the bacterial load of the soil attached to class 2 (HDPE) polythene. After eight weeks of submergence in mangrove soil, soil attached to class 1 and class 3 polythene mostly had Bacillus (Staphylococcus predominated in class 2 polythene). While most of the isolates were capable of producing hydrolytic enzymes such as amylase and gelatinase, lipolytic activity was low. Class 2 HDPE suffered the greatest biodegradation. Rev. Biol. Trop. 55 (3-4): 777-786. Epub 2007 December, 28.
\end{abstract}

Key words: Mangrove soil, heterotrophic bacteria, plastic pollution, microbial degradation, biodegradation, hydrolytic enzymes.

Plastic is the most versatile synthetic 'manmade' substance, created out of the fossil fuel resources that enable most of the industrial and technological revolutions of the $19^{\text {th }}$ and $20^{\text {th }}$ centuries. During the past 25 years plastic materials have gained widespread use as they have been increasingly used in food, clothing, shelter, transportation, construction, medical and leisure industries. Plastics are composed of petroleum based materials called resins (e.g., polythene and polypropylene) - materials that are resistant to biodegradation. Because of this resistance, plastics that are disposed in landfills will remain in their original form in perpetuity. Plastic offer a number of advantages over alternative materials - they are lightweight, low cost, extremely durable and relatively unbreakable. Production of plastic has grown significantly in the last 30 years averaging an annual growth rate of $10 \%$. A general estimate of world wide plastic waste generation is annually about 57 million tons.

However, plastic materials also have several disadvantages, the most important being that they do not break down in the environment. Every year, large volume of plastics are disposed of in US land fills - in 1995 alone, an estimated 20 millions tons of plastics products were disposed of in landfills. Because of their buoyancy, long term persistence and ubiquity in the marine environment, plastic waste poses a variety of hazards to marine life (Spear et al. 
1995). In recent years there has been growing public concern over environmental deterioration associated with the disposal of conventional plastics. Discarded plastics, besides being highly visible are a rapidly increasing percentage of solid waste in landfills, resistant to biodegradation leading to pollution, harmful to the natural environment. These problems have made plastic waste a major focus in the management of solid waste. For marine waters, an international accord (the MARPOL [marine pollution] Treaty) has been ratified to deal with sources of pollution, including plastics. In addition to the impacts on marine animals, plastic debris also aesthetically degrades the environment and has impact on our economy, human health and safety.

Considering the diversity of life on earth surface, prokaryotes offer maximum diversity in terms its habitat occupation and physiologi$\mathrm{cal} /$ metabolic capabilities. They are present in every possible niche on earth, whether moderate or extreme. While archaebacteria are specialised to live in extremes of temperature, $\mathrm{pH}$, salinity and pressure other forms of prokaryotes are capable of occupying all other possible ranges. Their survival capabilities are proved to be remarkable which is to a great extent made possible by the fragility of their genomes, which undergoes mutation at very high frequency when compared to other forms of life. Most of the biodegradation studies on plastics are being carried out using microorganims.

Mangroves are considered as areas of high biological productivity, including the microbial community. Because of the typical vegetation, root systems and reduced tidal flow there is a large scale accumulation of organic, inorganic and plastic wastes in this very important ecosystem. Most of the organic wastes undergo microbial degradation and contributes to the biological productivity either directly or indirectly. Heterotrophic bacteria utilise organic matter as a source of energy converting complex organic matter into the final metabolic waste products such as water and carbon dioxide. As a result of this natural process wastes are either used up or converted into a less harmful form.
Furthermore, heterotrophic bacteria show high degree of diversity in their metabolic capabilities resulting from a great range of enzymes with different substrate specificities.

There is considerable research on the development of biodegradable plastics as well as on the degradation of existing plastics using microorganisms. Since microorganisms are capable of degrading most of the organic and inorganic materials, there is lot of interest in the microbial degradation of plastic and polythene waste material. Kambe et al. (1995) isolated and characterized a bacterium from soil which utilizes polyester polyurethane as a sole carbon and nitrogen source. Two strains with good polyurethane degrading activity were isolated and identified as Comamonas acidovorans. Oda et al. (1998) studied the Polycaprolactone depolymerase produced by the bacterium Alcaligenes faecalis. He isolated several bacteria capable of degrading polycaprolactone (PCL) from soil and activated sludge.

Imam et al. (1999) investigated the degradation of starch-poly (b-hydroxybutyrate-Cob-hydroxyvalerate) bioplastic in tropical coastal waters. They reported that significant biodegradation occurred only after colonization of the plastic, a parameter that was dependent on the resident microbial populations. Webb et al. (2000) studied the fungal colonization and biodeterioration of plasticized polyvinyl chloride in situ an ex situ conditions. These results suggest that microbial succession may occur during the long periods of exposure in in situ. They have identified Aureobasidium pullulans was the principal colonizing fungus and a group of yeasts and yeast-like fungi, including Rhodotorula aurantiaca and Kluyveromyces spp. Incidence of marine and mangrove bacteria accumulating polyhydroxy alkanoates on the mid-west coast of India has been reported by Rawte et al. (2002). Microbial degradation of Poly ( $\varepsilon$-caprolactone) (PCL)-Poly vinyl butyral (PVB) blends have been studied by Rohindra et al. (2003). Recent research (Kathiresan 2003) has revealed that the high diversity of the microorganisms in the mangrove soil is capable of degrading the plastics, although at a slower rate. 
Low-density polyethylene (LDPE), accounts for $60 \%$ of the total plastic production and the most commonly found solid waste is the non-degradable polythene carry bag. The indiscriminate use of polythene shopping bags by the public is increasingly becoming an environmental problem in Fiji. Although Department of Environment has come with awareness campaigns on 3R's (reduce, reuse and recycle), most of the coastal environments of Fiji are littered with large quantity of this highly recalcitrant waste material. The present study has been taken up with an objective of estimating the diversity of the mangrove microflora, with special emphasis on determining their ability to degrade the polythene wastes.

\section{MATERIALS AND METHODS}

Estimation of the heterotrophic bacteria and fungi in the mangrove soil sample: soil samples were collected in sterile polyethylene bags from three different sites of the mangrove at Suva, Fiji Islands (Between 17 $28^{\prime}-17^{\circ} 51^{\prime}$ $\mathrm{S}$ and $\left.178^{\circ} 25^{\prime}-179^{\circ} 19^{\prime} \mathrm{E}\right)$. The samples were serially diluted and pour plated in sterile nutrient agar and potato dextrose agar to estimate and isolate the heterotrophic bacteria and fungi respectively. The plates were incubated at 37 ${ }^{\circ} \mathrm{C}$ for $48 \mathrm{~h}$. After incubation, plates with 30 300 colonies were chosen for counting and the total plate count for bacteria and fungi was expressed as number of colony forming units (cfu) per gram of soil.

Characterization of the heterotrophic bacteria from the mangrove soil sample: after counting and estimation of total bacterial load, morphologically different colonies were picked up using a sterile inoculation needle and aseptically transferred to sterile nutrient agar slants for further characterization. A total of 43 isolates were chosen for characterization. The isolates were characterized up to genera using the identification scheme provided in Bergey's manual of determinative bacteriology (Buchanan and Gibbons 1979) based on vari- ous staining and biochemical reactions such as Gram-staining, spore staining, motility, oxidation fermentation $(\mathrm{O} / \mathrm{F})$ test, Kovac's oxidase and catalase tests.

Evaluation of hydrolytic enzymes produced by the heterotrophic bacteria from mangrove soil: nutrient agar supplemented with $1 \%$ starch, $1 \%$ gelatine and $1 \%$ tween 80 to get starch agar, gelatine agar and lipid agar respectively. The media were sterilised at $15 \mathrm{lb}$ for 15 min. About $15-20 \mathrm{ml}$ of the sterilised media was poured into sterile petridishes to get the sterile plates of respective media. The plates were surface dried overnight and spot inoculated with the bacterial isolates (4 isolates per plate). The plates were incubated at $37{ }^{\circ} \mathrm{C}$ for $48 \mathrm{~h}$. After incubation the surface of the starch agar plates was flooded with Gram's iodine solution and the gelatine agar plates with mercuric chloride solution. Clear zone around the culture on starch agar plates and gelatine agar plates were considered positive for amylase and gelatinase activity respectively. Lipase activity was indicated by the change in the opacity of the lipid agar around the positive cultures.

Classification of plastics: Perkin Elmer (Netherlands) Pyris 6 differential scanning calorimeter (DSC) was used to identify the different types of polythene samples used for biodegradation studies. The samples were weighed before DSC measurement. Scanning was done from $20{ }^{\circ} \mathrm{C}$ to $200{ }^{\circ} \mathrm{C}$ under nitrogen flow.

Biodegradation of plastics: mangrove soil from three sites at the study area was collected as mentioned in section 2.1. A microcosm of this environment was replicated in lab by keeping the soils in $59 \mathrm{~cm}$ (length) $\mathrm{x}$ $36 \mathrm{~cm}$ (width) x $21 \mathrm{~cm}$ (depth) plastic crate. The water level was maintained in such a way to keep the soils under slightly submerged condition. Three classes of polythene used to make carry bags were used for the degradation studies. Definite size $\left(5 \mathrm{~cm}^{2}\right)$ of these were cut out from these bags, weighed and buried in the soil at a depth of $5 \mathrm{~cm}$. Class 1 was identified 
as LDPE and class 2 and 3 as HDPE based on melting point curves using differential scanning calorimeter. Fifteen pieces of each sample were used for the experiment and the mean weight was taken. The samples were removed after fourth and eighth week, washed and dried. Then the mean weight was recorded.

\section{Estimation and char- acterization of the hetero- trophic bacteria attached to different classes of poly-} thene: the soils attached to the different polythene surfaces were collected by washing them with sterile distilled water into a sterile conical flask. The estimation and characterization of heterotrophic bacteria attached to different classes of polythene was carried out as described. The hydrolytic enzyme activities of these microorganisms were also evaluated as described previously.

\section{RESULTS}

Total aerobic plate count of heterotrophic bacteria and fungi is presented in Table 1 . The total heterotrophic bacteria (THB) load from different sites varied from $1.07 \times 10^{4}$ to $1.35 \times 10^{4}$, while the fungal load varied from $3 \times 10^{2}$ to $6 \times 10^{3}$ colony forming units (CFU) per gram. There was not any significant variation among the THB and fungal load from different
$\%$ weight loss of different plastic material

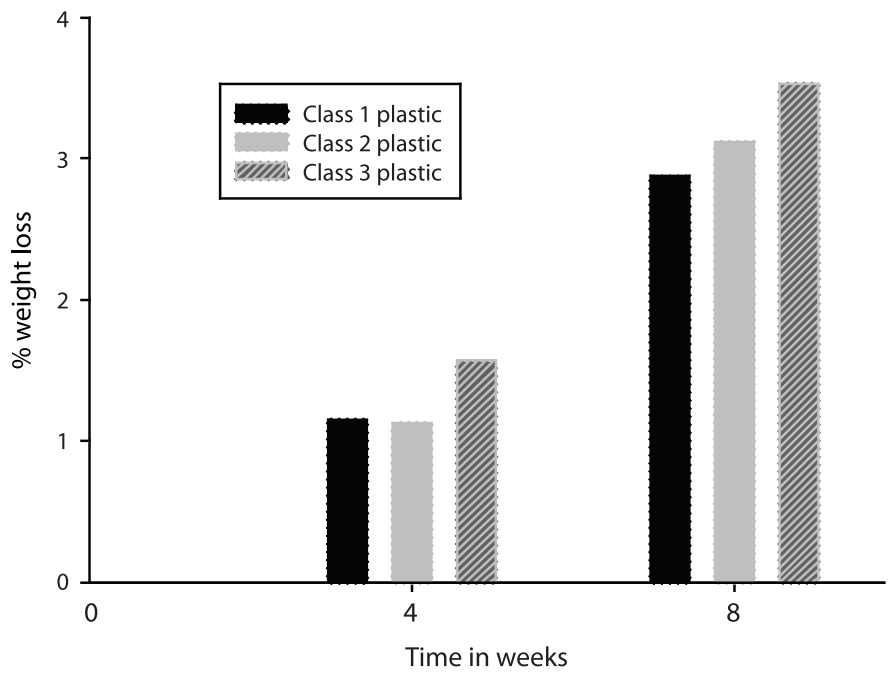

Fig. 1. Percentage of weight loss observed in the different classes of polythene treated with mangrove soil microflora over a period of eight weeks. sites. The fungal load was found to be considerably lower when compared to THB load.

Characterization of the bacterial isolates (Table 2) revealed that Bacillus was the dominant genera in the mangrove soil. Other genera such as Micrococcus, Listeria and Vibrio were also encountered in the mangrove soil samples. Table 2 also represents the load and generic composition of the THB in the soil attached to different polythene samples used for degradation studies. Results clearly revealed the changes in THB load and generic composition of the bacterial flora. Results indicated that the soil attached to the class 2 polyethylene (HDPE) had a very high bacterial load $\left(112 \times 10^{9} \mathrm{cfu} / \mathrm{g}\right)$ compared to the other two types of polyethylene.

The evaluation of the production of hydrolytic enzymes by the isolated heterotrophic

TABLE 1

Load of heterotrophic bacteria and fungi in the mangrove soil from Suva, Fiji

$\begin{array}{lccc}\text { Parameter } & \text { Site 1 } & \text { Site 2 } & \text { Site 3 } \\ \text { Heterotrophic bacterial load (cfu/gm) } & 1.35 \times 10^{4} & 2.8 \times 10^{4} & 1.07 \times 10^{4} \\ \text { Fungal load }(\mathrm{cfu} / \mathrm{gm}) & 3 \times 10^{2} & 2 \times 10^{3} & 6 \times 10^{3}\end{array}$


TABLE 2

The mean heterotrophic bacterial load and different genera encountered in the initial mangrove soil sample and the soil samples adhered to different classes of polythene

$\begin{array}{lcc}\begin{array}{l}\text { Sample } \\ \text { Mangrove soil }\end{array} & \begin{array}{c}\text { Heterotrophic bacterial } \\ \text { load (cfu/gm) }\end{array} & \begin{array}{c}\text { Genera found (\%) } \\ \text { Bacillus } 77^{*} \\ \text { Micrococcus } 12 \\ \text { Listeria } 9 \\ \text { Vibrio } 2\end{array} \\ \text { Soil attached to Class 1 polyethylene LDPE } & 1.74 \times 10^{4} & \begin{array}{c}\text { Bacillus } 85.7 \\ \text { Listeria } 14.3 \\ \text { Soil attached to Class II polyethylene HDPE }\end{array} \\ \begin{array}{l}\text { Soil attached to Class III polyethylene HDPE } \\ \text { Bacillus } 28.6\end{array} \\ \text { Staphylococcus } 71.4\end{array}$

*Values in the parenthesis indicate percentage incidence of each genus

bacteria from the soil attached to different classes of polyethylene also showed a lot of variability when compared to that of the isolates from original mangrove soil (Table 3). While the bacterial isolates from class 2 polyethylene had reduced gelatinase and amylase activity there was considerable improvement in lipolytic activity. In case of the isolates from class I and class 3 the ability to produce gelatinase and amylase was found to be higher.

Furthermore, the biodegradation was assessed in terms of percentage weight loss (Fig. 1). It was found that a reduction in the mean weight of all three classes of plastics has taken place indicating the degradation. It was found that class 3 polyethylene (HDPE) had undergone more biodegradation when compared to the other two.

\section{DISCUSSION}

The results revealed that the heterotrophic bacterial load in the mangrove soil from the study area was in the range of $10^{4}$ to $10^{5} \mathrm{cfu} / \mathrm{gm}$ which was nearly similar to the observations of Dhevendran et al. (1987) who reported $33.2 \times 10^{5} \mathrm{cfu} / \mathrm{gm}$ bacterial population from Astamudy lake sediment. The THB load encountered in the present study was one log lower than those reported by Kathiresan (2003) in the mangrove soils from India. However,

TABLE 3

Hydrolytic enzyme producing ability of the bacterial isolates from the initial mangrove soil sample and soil samples adhered to different classes of polyethylene

Sample

Mangrove soil

Soil attached to Class I polyethylene LDPE

Soil attached to Class II polyethylene HDPE

Soil attached to Class III polyethylene HDPE
Percentage of isolates capable of producing

$\begin{array}{ccc}\text { Amylase } & \text { Gelatinase } & \text { Lipase } \\ 46.5 & 81.4 & 4.7 \\ 92.7 & 64.3 & 0 \\ 28.6 & 28.6 & 14.3 \\ 92.7 & 92.7 & 7.1\end{array}$


such variation can occur between different geographical locations owing to differences in the environmental parameters. However the bacterial load was relatively lower when compared to results from various researchers (Hermansson et al. 2001, Dellamatrice et al. 2004, Kolb et al. 2003). Detritus originating from the breakdown of mangrove leaves and woody tissues could be the major energy sources for the thriving microbial population. Estuarine sediments are rich in organic matter than that of the adjacent sea (Nixon and Lee 1982). The organic production is favoured by vegetation, texture of the sediment and degree of oxidation. Besides this the rain water run off through rivers, prevailing current and depth of occurrence also play and important role in the accumulation of organic mater (Purandara et al. 1987). The high load is possible as the mangrove soil is very rich in nutrients and organic matter that will help proliferation of different types of microorganisms. The fungal population is low when compared to bacterial population in the mangrove sediment. This may be due to the competition from the bacterial population and also due to the soil $\mathrm{pH}$.

The predominant morphological group observed was Gram positive bacteria. Higher percentage of Gram positive bacteria was reported by Devendran et al. (1987) in the mangrove sediment from Pichavaram, India. Characterization of the bacterial isolates revealed that Bacillus was the dominant genera in the mangrove soil. It has been reported that Gram positive bacteria such as Bacillus are one of the important components of the soil microbial community (Prescott et al. 1996). This could be due to the spore forming nature of Bacillus as endospore forming bacteria are widely distributed in soil habitats. Soil conditions are often extremely variable and endospores are an obvious advantage in surviving periods of dryness or nutrient deprivation. Other genera such as Micrococcus, Listeria and Vibrio were also encountered in the mangrove soil samples. Vibrio is a typical halophilic bacterium and its presence in mangrove soil was obvious. Occurrence of other two genera such as Listeria and Micrococcus in the soil samples has also been previously reported (Prescott et al. 1996).

Results of the load and generic composition of the THB in the soil attached to different polythene samples used for degradation studies clearly revealed the changes in these parameters in the soils attached to different classes of polythene. Results indicated that the soil attached to the class 2 polythene (HDPE) had a very high bacterial load $\left(112 \times 10^{9} \mathrm{cfu} / \mathrm{g}\right)$ compared to the other two types of polyethylene. This indicates the ability of the bacteria attached to the class 2 polythene to use it as a source of nutrient and resultant growth. Abundance of polymer degrading microorganisms in a seabed solid waste disposal site has been reported by Ishigaka et al. (2000). They had reported that population sizes of polymer degrading microorganisms (PDM's) correlated to those of heterotrophic bacteria and the counts of aerobic heterotrophic bacteria and PDM's were found to be higher. An increase of bacterial population correlated with the signs of disintegration of mechanical properties of natural polymer (NP) films, indicating the role of biotic component in degradation process (Orhan et al. 2004). Our findings are also similar to the observations of Imam et al. (1999) who investigated the degradation of starch-poly (b-hydroxybutyrate-Co-bhydroxyvalerate) bioplastic in tropical coastal waters. They observed that significant biodegradation occurred only after colonization of the plastic, a parameter that was dependent on the resident microbial populations. Therefore, it can be reasonably inferred that an increase in the bacterial load has correlation with degradation of the polymer. Webb et al. (2000) studied the fungal colonization and biodeterioration of plasticized polyvinyl chloride in situ an ex situ conditions and suggested that microbial succession may occur during the long periods of exposure in in situ. They have identified Aureobasidium pullulans was the principal colonizing fungus and a group of yeasts and yeast-like fungi, including Rhodotorula aurantiaca and Kluyveromyces spp. 
The characterization of the bacterial genera also showed the variation in terms of the dominant genera in the soil attached to different classes of polythene. While class 3 (HDPE) and class I (LDPE) polythene had Bacillus as the dominant genera, class 2 polythene had Staphylococcus as the dominant genera. Although this point has not been proven yet, there is a possibility that these different genera could be responsible for the biodegradation of different types of polythene. For example, Staphylococcus must be contributing more towards the degradation of class 2 polythyene while Bacillus towards class 1 and class 3 polyethylene. Previous studies reported that Bacillus sp. showed more degradation in different blends of poly ( $\varepsilon$-caprolactone) and poly (vinyl butyral) (Rohindra et al. 2003). The presence of other genera apart from the dominating ones shows that more than one bacteria could be responsible for the degradation of a particular type of polythene. The field tests such as burying plastic samples in soil have been widely conducted for their biodegradation because of the similarity to actual conditions of use or disposal. The biodegradation of plastics proceeds actively under different soil conditions according to their properties, because the microorganisms responsible for the degradation differ from each other and they have their own optimal growth conditions in the soil (Orhan et al. 2004).

The evaluation of the production of hydrolytic enzymes by the isolated heterotrophic bacteria from the soil attached to different classes of polythene also showed a lot of variability when compared to that of the isolates from original mangrove soil. While the bacterial isolates from class 2 polythene had reduced gelatinase and amylase activity there was considerable improvement in lipolytic activity. In case of the isolates from class I and class 3, the ability to produce gelatinase and amylase were found to be higher. The results are indicative of variability in the physiological capabilities of isolates attached to different classes of polythene. Studies revealed that the Bacillus sp. consume waste thousand times faster than the types of bacteria that are naturally present in the waste. Also, the mangrove microflora were found to be diverse with respect to enzymatic activities (Zahir et al. 2001, Rawte et al. 2002). The mechanism of degradation of polythene and plastic is not fully known. This may be due to the compounds secreted extracellularly by the microbes that may break the complex molecular structure of plastics (Kathiresan 2003). The degradation of different types of polymers by microorganisms under laboratory condition were reported by (Nakayama et al. 1997, Kesal et al., 1997, Leferve et al. 2001). Several workers had reported that the enzymatic activity of the microorganism is responsible for the degradation of polythene and several biodegradable plastics. Uchida et al. (2000) has reported that during degradation, a lipase activity was observed in the culture broth properties of a bacterium which degrades a biodegradable plastic. It is also reported that both protease and esterase activities, which may be involved in the degradation of plastics, were constitutively detected in the culture broth (Kambe et al. 1999).

The biodegradation was assessed in terms of percentage weight loss (Fig. 1). Previous researchers (Abou-Zeid et al. 2001) have used this method to carry out similar studies. It was found that a reduction in the mean weight of all three classes of plastics has taken place indicating the degradation. The reduction could be due to the hydrolysis process, which is comparable to the findings Grima et al. (2000) who has reported that in polymer degradation the mechanisms are typically biological hydrolysis and biological oxidation. It was found that class 3 polyethylene (HDPE) had undergone more biodegradation when compared to the other two. The degradation levels were comparable to the findings of Kathiresan (2003). This could be due to the additives present in the plastic. The high percentage weight loss of ploythene and plastic in our results reveals mangrove soil can be a source of factors responsible for the degradation of plastic materials. The factors may include microbes, moisture, heat, etc. The mangrove soil maintains moisture by 
tidal water flood during high tide and the soil gets heated during low tide when exposed to sunlight as well due to exothermic reactions of biological compounds in the soil (Kathiresan and Bingham 2001). Besides these abiotic conditions, microbial counts were also found to be high, perhaps favouring the degradation of plastics.

The difference in the melting point and delta $\mathrm{H}$ also shows the effect of additives. For example, the melting point and delta $\mathrm{H}$ of class 3 polythene is less compared to class 2 polythene although both are HDPE. This shows that due to the additives, the bonding strength in the polymer may have been reduced thus less energy and temperature was required to melt the plastic. Furthermore, the bonding in HDPE is linear and LDPE has branching in the chain. According to this the degradation rate should be more in class 1 polythene than in class 2 and 3. However this is not the case and this could be due to lack of additives in the LDPE. The additives increase the degradation rate by decreasing the melting point, the bonding strength and the glass transition temperature of the polymer. However, this research was very basic. More investigation can be done in order to get better understanding on the biodegradation of polythene. For example, in this research the degradation has been found based on the mean weight loss. Other properties such as the thickness, tensile strength and visual observation can also be used to find the degradation rate of the polymer.

The microbiological process which lead to the destruction of natural polymers such as starch, cellulose and proteins during exposure to soil are well understood (Colin 1981, Kenneth 1993). The useful lifetimes (normally measured by embrittlement) of films prepared from synthetic polymers when exposed to soil are now of relevance to many areas. The manner and rate of degradation of a polymer are dependent on the mechanism of degradation and on the acceleration of process. A variety of environmental factors such as oxygen, temperature, sunlight, water, stress, living organisms and pollutants may affect the degradation of polymer. Therefore, it is important from the viewpoint of soil microbiology to determine the biodegradability of plastics and microorganisms responsible for it in each soil condition for reaching the general conclusion on its biodegradability.

In conclusion, the results revealed that the heterotrophic bacteria isolated from mangrove soil were capable of producing hydrolytic enzymes that can contribute to the degradation of polythene used in the present study. Also, there was a selection of different genera towards different classes of polythene indicating that different genera could be responsible for the degradation of different types of polythene. Results also showed that class 3 polythene had undergone more biodegradation. This could be due to the presence of additives which can increase the degradation rate by decreasing the melting point, delta $\mathrm{H}$, bonding strength and glass transition temperature.

\section{ACKNOWLEDGMENTS}

The authors express their gratitude to the Director, School of Biological, Chemical and Environmental Sciences, The University of the South Pacific, for providing the facilities.

\section{RESUMEN}

Se determinó la diversidad y la carga de bacterias heterotróficas, así como los hongos asociados al suelo del manglar de Suva, Islas Fiji, utilizando el método de conteo de placas, usado también para medir la capacidad de bacterias aisladas para producir enzimas hidrolíticas como amilasa, gelatinasa y lipasa. La carga bacteriana heterotrófica resultó ser considerablemente más alta que la carga funguicida. Hubo predominancia de bacterias "Gram-positivas" del género de Bacillus. Otros géneros encontrados fueron Staphylococcus, Micrococcus, Listeria y Vibrio. La eficacia de esta microflora en la degradación del polietileno comercial de bolsas hechas de polietileno de alta densidad (HDPE) y de baja densidad (LDPE) fue estudiada en el laboratorio por un periodo de ocho semanas. La biodegradación fue medida en términos de pérdida de peso, la cual indicó una disminución del $5 \%$. Después de ocho semanas en el suelo de un manglar, el polietileno clase 1 y clase 3 contenía fundamentalmente Bacillus, pero en el 
polietileno clase 2 predominó el género Staphylococcus. Mientras que la mayoría de bacterias aisladas fueron capaces de producir enzimas hidrolíticas como la amilasa y la gelatinasa, la actividad lipolítica fue muy baja. La clase 2 (HDPE) experimentó la mayor biodegradación.

Palabras clave: Suelo de manglar, bacteria heterotrófica, contaminación plástica, degradación microbiana, biodegradación, enzimas hidrolíticas.

\section{REFERENCES}

Abou-Zeid, D.M., R.J. Muller \& W.D. Deckwer. 2001. Degradation of natural and synthetic polyesters under anaerobic conditions. J. Biotechnol. 86: 113-126.

Buchanan, R.M. \& N.E. Gibbons. 1979. Bergey’s Manual of Determinative Bacteriology. Williams and Wilkins, Baltimore, Maryland, USA.

Colin, G., J.D. Cooney, D.J. Carlsson \& D.M. Wiles. 1981 Deterioration of plastic films under soil burial conditions. J. Appl. Polym. Sci. 26: 509-519.

Dellamatrice, P.M \& R.T.R. Montero. 2004. Isolation of diuron-degrading bacteria from treated soil. Int. J. Br. Arch. Biol. Technol. 43: 999-1003.

Devendran, K., K. Maya \& P. Natarajan. 1987. Studies on microbial ecology of south- west coast of India. Proceedings of the National Seminary on Estuarine Management, New Delhi, India, p 425.

Imam, S.H., S.H. Gordon, R.L. Shogren, T.R. Tosteson, N.S. Govind \& R.V. Greene. 1999. Degradation of starchpoly (b-Hydroxybutyrate-Co-b- Hydroxyvalerate) bioplastic in tropical coastal waters. Appl. Environ. Microbiol. 65: 431-437.

Ishigaka, T., W. Sugano, M. Ike, Y. Kawagoshi \& M. Fujita. 2000. Abundance of polymers degrading microorganisms in sea based solid waste disposal site. J. Basic Microbiol. 40: 177-186.

Grima, S., V. Bellon-Maurel, P. Feuilloley \& F. Silvestre. 2000. Aerobic biodegradation of polymers in solid state conditions: A review of environmental and physicochemical parameter settings in laboratory simulations. J. Poly. Environ. 8: 183-195.

Hermansson, A. \& P. Eric Lindgren. 2001. Quantification of ammonia-oxidizing bacteria in arable soil by realtime PCR. Appl. Environ. Microbiol. 67: 972-976.

Kesal, C.D., C.V. Wauven \& C. David. 1997. Biodegradation of polycap-rolactone and its blends with poly (vinyl alcohol) by microorganisms from a compost of house hold refuse. Polym. Degrad. Stab. 55: 107-113.

Kathiresan, K. 2003. Polyethylene and plastic degrading microbes in an Indian mangrove soil. Rev. Biol. Trop. 51: 629-634.

Kathiresan, K \& B.L. Bingham. 2001. Biology of mangrove ecosystems. Advances Mar. Miol. 40: 81-251.

Kambe, T.N., Y.S. Akutsu, N. Nomura, F. Onuma \& T. Nakahara. 1999. Microbial degradation of polyurethane, polyester polyurethanes and polyether polyurethanes. Appl. Microbiol. Biotechnol. 51: $134-140$.

Kenneth, E.J., A.L. Pometto \& Z.L. Nikolov. 1993. Degradation of degradable starch-polythene plastics in a compost environment. J. App. Env. Mic. 59: $1255-1261$.

Kolb, S., C. Knief, S. Stubner \& R. Conrad. 2003. Quantitative detection of methanotrophs in soil by novel. pmoA-targeted real-time PCR assays. Appl. Environ. Microbiol. 69: 2423-2429.

Lefevre, C., A. Tidjani, C.V. Wauven \& C. David. 2002. The interaction mechanism between microorganisms and substrate in the biodegradation of polycaprolactone. J. Appl. Poly. Sci. 83: 1334 -1340.

Nakayama, A., N. Kawasaki, Y. Maeda, I. Arvanitoyannis, S. Aiba \& N. Yamamoto. 1997. Study on the biodegradability of poly (valerolactone co-L-lactide). J. Appl. Poly. Sci. 66: 741-748.

Nixon, S.W \& V. Lee. 1982. The flux of carbon, nitrogen and phosphate betweens coastal lagoons and offshore waters. Tech. Paper Mar. Sci. 33: 7-14.

Oda, Y., N. Oida, T. Urakami \& K. Tonomura. 1998. Polycaprolactone depolymerase produced by the bacteriaum Alcaligenes faecalis. FEMS Micobiol. Lett. 150: 339-343.

Orhan, Y., J. Hrenoviæ \& H. Büyükgüngör. 2004. Biodegradation of plastic compost bags under controlled soil conditions. Acta Chim. Slov. 51: 579-588.

Prescott, L.M., J.P. Harley \& A.D. Klein. 1996. Microbiology. McGraw Hill, New York, New York, USA.

Purandara, B.K. \& Y.L. Dora. 1987. Studies on texture and organic matter in the sediments of Vembanad lake 
nearshore sediments. Proceedings of the National Seminary on Estuarine Management, New Delhi, India, p 449.

Rawte, T., M. Padte \& S. Mavinkurve. 2002. Incidence of marine and mangrove bacteria accumulating polyhydroxyalkanoates on the mid-west coast of India. World J. Microbiol. 18: 655-659.

Rohindra, D.R., P. S. Preeti \& J.R. Khurma. 2003 Biodegradation study of poly ( $\varepsilon$-caprolactone)/poly (vinyl butyral) blends. South Pac. J. Nat. Sci. 21: 47-49.

Spear, L.B., D.G. Ainley \& C.A. Ribic. 1995. Incidence of plastics in seabirds from the tropical Pacific 198491: Relation with distribution of species, sex, age, season, year and body weight. Mar. Environ. Res. 40: $123-141$.

Uchida, H., T.N. Kambe, Y.S. Akutsu, N. Nomura, Y. Tokiwa \& T. Nakahara. 2000. Properties of a bacterium, which degrades solid Poly (tetramethylene succenate)- co-adipate, a biodegradable plastic. FEMS Microbiol. Lett. 189: 25-29.

Webb, J.S., M. Nixon, I.M. Eastwood, M. Greenhalgh, G.D. Robson \& P.S. Handley. 2000. Fungal colonization and biodeterioration of plasticized polyvinyl chloride Appl. Environ. Microbiol. 66: 3194 -3200.

Zahir, Z.A., M.M. Ateeq ur Rehman \& A. Muhammed. 2001. Soil enzymes research: A Review. J. Biol. Sci. 1: $299-307$ 